\title{
Peter Kevin SPINK, Beyond Public Policy: A Public Action Languages Approach
}

\section{Kate Precious}

\section{(2) OpenEdition \\ 1 Journals}

Electronic version

URL: https://journals.openedition.org/irpp/2239

DOI: 10.4000/irpp.2239

ISSN: 2706-6274

Publisher

International Public Policy Association

\section{Printed version}

Date of publication: 30 October 2021

Number of pages: 238-240

ISSN: 2679-3873

\section{Electronic reference}

Kate Precious, "Peter Kevin SPINK, Beyond Public Policy: A Public Action Languages Approach", International Review of Public Policy [Online], 3:2 | 2021, Online since 01 August 2021, connection on 16 December 2021. URL: http://journals.openedition.org/irpp/2239 ; DOI: https://doi.org/10.4000/irpp. 2239

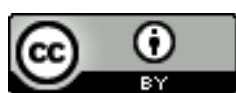

International Review of Public Policy is licensed under a Creative Commons Attribution 4.0 International. 


\section{Book Review}

\section{Peter Kevin SPINK, \\ Beyond Public Policy: A Public Action Languages Approach}

\section{Kate Precious}

Department of Politics, Languages and International Studies, University of Bath, England

Beyond Public Policy: A Public Action Languages

Approach

Peter Kevin Spink

Spink, Peter Kevin, Cheltenham (UK) \& Northampton (USA): Edward Elgar Publishing, 2019, 256 p., ISBN 9781788118743. Hardback: £80.00, \$125; eBook: $£ 25.00 ; \$ 40.00$

2019 
Peter Kevin Spink's book is an elegantly written critique of the tendency, in academia and society at large, to take a government-centric approach to public policy. In particular, Spink argues, we focus too much on the impact that languages and social constructions have on government decisions and not enough on their wider impact. As a result, we only see part of the picture. Evidencing his key arguments through a series of historical sketches and quotations spanning both several centuries and also the globe, he calls for a "public action languages approach" to the study of social constructions, discourse, and narratives in public policy. His approach is 'public' in the sense that it encompasses all civil society actors who seek to mitigate social problems, whether within or outside the state. It is 'action' focused because it looks at what 'can be done' in a wider sense than what government can (or should) do. And it is a 'languages' approach because it acknowledges the heterogeneity of the languages used by the public to talk about social problems and social realities. The book is aimed at public policy scholars in general but is particularly of interest to those researching or interested in framing social constructions or discourse analysis - most likely from a critical theory standpoint.

The interdisciplinarity that has characterised much of Spink's career to date is evident in his writing which draws on many diverse examples. Indeed, much of the book consists of a tapestry of examples woven to illustrate his three key arguments: that there are myriad different social languages in the public affairs arena; that no centralised language, system or process can accurately reflect them all; and that there are as many public affairs languages outside the sphere of formal governance as there are inside. After these key arguments are set out in the introduction, they are further developed through the chapters that follow. Spink uses these arguments to support his central thesis, as summarised in the conclusion, that public policy scholars should "look for and recognise the multiplicity of what is taking place" (p. 200) both inside and outside government. Methodologically, this is essentially a documentary analysis framed by Spink as a "collection of stories" (p. 29). Epistemologically, it is very definitely presented as an 'approach' and not a 'theory', deliberately leaving it open to the reader to utilise the information provided in the way they deem most appropriate. Certainly, the interdisciplinary approach espoused by Spink has much to offer public policy . Each policy area has its own associated disciplines, such as disability studies for disability policy, or feminism for equality policy: without an understanding of these disciplines, no scholar can take a truly holistic approach. This is not a new idea, but it is one that, on the whole, public policy scholars have been slow to adopt.

From a public policy perspective, this book is a welcome attempt to diversify approaches and to consider the role played by civil society actors, such as churches, charities and third sector organisations. The central arguments are clearly supported by a wealth of historical and current examples taken from a wide range of geographical and cultural contexts. From this, public policy scholars can identify new areas of public policy to explore outside of the traditional, government-centric approach. While democratisation has long been a concern of public policy, and particularly of lobbying, it has less often engaged with the emancipation scholarship more commonly associated with political science, despite there being many interdisciplinary learning points from such a collaboration. This approach provides an opportunity both for collaboration and for a welcome recognition of the role of non-traditional actors in the policy process. It could even be viewed as democracy in action, since it leaves the next step in the process open.

Qualitative approaches to public policy have become more mainstream and so have discussions of social constructions and framings. For this reason, the importance of languages used by governments and policy stakeholders has been recognised in the literature, alongside the 
importance of documents as records of such language. Spink's approach capitalises on this trend in order to widen the scope of inclusion of 'action languages' from additional sources; his approach also turns the trend on its head by minimising the importance of dominant constructions and frames that characterises most public policy research. Instead of framing congruence, he recommends focusing on framing diversity. There is a tension here: one of the most difficult things about public policy, for both governments and civil society actors, is that there are so many competing frames, but only a limited number can realistically be enacted through policy. It is not possible, as the adage goes, to please all of the people all of the time. While Spink's desire to move away from a government-centric approach explains his diversity approach, it arguably makes things more difficult for civil society actors who can only do so much without involving the government. Recognising the diversity of languages (and frames) and celebrating it is a valid approach but public policy has always been pragmatic in outlook, with a focus on implementation, and there are difficulties in the implementation of such an approach. In short, there is simultaneously a risk and an opportunity in this non-government-centric approach and this, in my view, is not adequately addressed in the book.

Indeed, although the approach proposed by Spink has the potential to be a fruitful one, the next steps remain unclear. Other than his desire to broaden the approach of public policy scholars, and presumably to democratise our understanding of policy, the aims of the book or what exactly Spink expects or hopes scholars will do with it - are shrouded in mystery. This is a deliberate choice to seek to "negotiate possibilities" (p. 200), but it does leave the book feeling incomplete. A negotiation needs suggestions to get started, and suggestions of what this approach might be used for appear to be deliberately omitted. This is, of course, a valid epistemological choice by the author; nonetheless, it is arguably not an epistemology that is widely supported in the public policy sphere. It is a truism that public policy seeks to solve problems - it tends to prefer this to talking about them. Thus, while there is undoubted value in moving away from a government-centric approach, this may be too big a change for the sector to embrace without a step-by-step plan. The book, in my view, would be improved by additional suggestions on what those steps could be: a plan, as well as a vision. In addition, while Spink states in his Introduction that he will begin by discussing the theory before moving on to case studies and examples, the book is decidedly light on theory. Again, this seems to be a deliberate decision - he describes an approach, not a theory, and provides more than enough examples to evidence his main arguments. This is, however, a novel approach for a public policy book, and may, unfortunately, discourage some readers from taking it further.

To conclude, this is an interesting and elegantly written book which is rich in thick description. It proposes a novel approach to public policy which will undoubtedly yield useful fruit if it is adopted. The relative lack of theory and strategic elements, however, may discourage some public policy scholars from taking it further. It is most likely to be of interest to those scholars already working on framing or on social constructions and it would also be of interest to those in other disciplines researching political representation, history or etymology. 